\title{
Gray mullets ameliorate organically enriched sediments below a fish farm in the oligotrophic Gulf of Aqaba (Red Sea)
}

\author{
T. Katz ${ }^{1}$, B. Herut ${ }^{2}$, A. Genin ${ }^{3}$, D. L. Angel ${ }^{1, *}$ \\ ${ }^{1}$ Israel Oceanographic \& Limnological Research (IOLR), National Center for Mariculture, PO Box 1212, Eilat 88112, Israel \\ ${ }^{2}$ IOLR, National Institute of Oceanography, PO Box 8030, Haifa 31080, Israel \\ ${ }^{3}$ Interuniversity Institute, Coral Beach, PO Box 269, Eilat 88000, Israel
}

\begin{abstract}
Net cage mariculture has an impact on the local benthos due to discharge of large amounts of particulate organic matter that alters the underlying sediment geochemistry. A field study was carried out to assess the use of the bottom-feeding gray mullet Mugil cephalus within benthic enclosures as a means to reduce the benthic impacts of fish farms. Four experimental $1 \mathrm{~m}^{3}$ enclosures were stocked with 12 gray mullets each (mean \pm standard error [SE] stocking density $1720 \pm 25 \mathrm{~g}$ enclosure $^{-1}$ ), while 3 identical enclosures without mullets served as controls. The enclosures had no bottom so that mullets could feed from and bioturbate the sediment. Sediment cores were taken from the 7 enclosures and from 3 bare (unenclosed sediment) sampling stations. Cores were analyzed for dissolved oxygen, total dissolved sulfides (TDS), water content and organic matter, as well as for the presence of macrofauna. Seventy days after the beginning of the field trial, a comparison between sediments inside the mullet enclosures and those in bare and enclosed control sites indicated that they had only 14 and $19 \%$ of the TDS and 69 and $44 \%$ of the sediment oxygen demand, respectively. These changes in the sediment geochemistry were accompanied by a steep increase in abundance of opportunistic mud snails Nassarius sinusigerus in the mullet enclosures. Essentially no snails or other macrofauna were found in the other treatments. One of the most dramatic changes observed in the mullet enclosures, as compared with the bare and enclosed controls, was the reduction in thickness of the organically enriched sediment layer by $5 \mathrm{~cm}$. The 'missing' sediment was equivalent to $2.6 \mathrm{~kg}$ organic carbon and corresponded to a mean carbon removal rate of $20.6 \mathrm{~g} \mathrm{~m}^{-2} \mathrm{~d}^{-1}$. While foraging for food and swimming near the sediment surface, mullets within the benthic enclosures resuspended detritus, increased the oxygen supply to the benthos and oxygenated buried organic matter, thereby dramatically improving the status of organically enriched, reduced sediments within a relatively short period of time. Therefore, deployment of detritivores in enclosures under active net cage fish farms may be a viable means to alleviate some of the environmental impacts of intensive mariculture.
\end{abstract}

KEY WORDS: Aquaculture $\cdot$ Sediment biogeochemistry $\cdot$ Gray mullet $\cdot$ Organic matter $\cdot$ Hydrogen sulfide $\cdot$ Fish farm $\cdot$ Red Sea

Resale or republication not permitted without written consent of the publisher

\section{INTRODUCTION}

Intensive net pen mariculture is generally carried out in sheltered or semi-sheltered, low-energy areas in coastal waters (Brown et al. 1987). Under low-energy conditions, waste food and feces from the net pens are

${ }^{*}$ Corresponding author. E-mail: angel@agri.huji.ac.il deposited onto the seafloor either directly below the farm or in the direction of the prevailing currents and can result in substantial accumulations of organic matter (OM) (Gowen et al. 1994, Silvert \& Sowles 1996). Accumulation of $\mathrm{OM}$ on the seafloor leads to sediment anoxia, sulfate reduction and drastic changes in the sediment porewater chemistry (Hall et al. 1990, Holmer \& Kristensen 1992). Such geochemical changes 
may alter the composition of the benthic community since many of the indigenous species may die or emigrate, and ultimately a low-diversity community of opportunistic biota will become established below and around the fish cages (Weston 1990, Yokoyama 1997).

During the past decade, fish farms have been established throughout many of the world's coastal regions, and there is increasing concern regarding the environmental impacts of these farms on the marine environment (Naylor et al. 2000). Several different physical or mechanical approaches have been proposed to reduce the benthic organic loads, including (1) systems to collect solid wastes before these reach the seafloor (Bergheim et al. 1991); (2) plowing of the seafloor below fish farms in order to enhance microbial decomposition of the OM therein (O'Connor et al. 1993); (3) periodic removal of the organically enriched sediments below fish farms (Braaten et al. 1983); and (4) site rotation of fish farm sites to allow seafloor recovery (Black 1998). Many of the proposed solutions have been tested but have not been implemented due to the high costs involved or the questionable benefits to the environment (Beveridge 1996).

Several workers have suggested the use of biological means to reduce fish farm impacts. In a series of laboratory experiments, Chareonpanich et al. (1994) demonstrated that the polychaete Capitella sp. could substantially reduce organic levels in organically enriched sediments; however, this approach was not tested in the field. Ahlgren (1998) placed the sea cucumber Parastichopus californicus inside salmon net pens to reduce the fouling of the nets and concluded that the holothurians grew by consuming detritus, thereby reducing the net particulate OM (POM) discharge from the net pens to the environment. Organisms that consume fish farm effluents either incorporate or metabolize these effluents. By harvesting these organisms, the nutrients and OM discharged by the fish farm can be removed.

In this study, we have chosen the gray mullet Mugil cephalus as a potential bioremediator since it consumes detritus as it ingests large quantities of sand and mud (Odum 1970, Laffaille et al. 1998, Shapiro 1998). Moreover, in a preliminary study, Porter et al. (1996) proposed that $M$. cephalus could improve the status of organically enriched marine sediments under fish farms. Since gray mullet has commercial value in many countries (Oren 1981), this could serve as an incentive for farmers to deploy them below fish cages and then harvest them as a supplementary ' $\mathrm{crop}^{\prime}$, thereby removing the consumed fish farm effluents from the sea. The aim of this study was to determine whether, and to what extent, mullet activity (feeding, digging and swimming) could reduce the organic load, diminish sediment hydrogen sulfide levels and increase the dis- solved oxygen (DO) level in the seabed, thereby reducing the impact of fish farms on the benthos. This objective was addressed by comparing temporal changes in sediment geochemistry and macrofauna within net enclosures stocked with gray mullets to those in unstocked net enclosures and in unenclosed sediments.

\section{STUDY SITE}

The study was carried out near the town of Eilat, Israel, at the northern tip of the Gulf of Aqaba, an oligotrophic, landlocked extension of the Red Sea. The study site was located at 22 to $23 \mathrm{~m}$ depth below the western net cage complex of the Ardag fish farm $\left(29^{\circ} 32.45^{\prime} \mathrm{N}, 34^{\circ} 58.40^{\prime} \mathrm{E}\right)$. The fish farm was established in 1988, and at the time of this study, annual production (mainly gilthead seabream Sparus aurata) was 900 US tons. The western net cage complex has a central steel pontoon $(3.2 \times 170 \mathrm{~m})$ and a series of round floating cages (12 m diameter; $10 \mathrm{~m}$ depth) attached to each side of the pontoon. The mean sedimentation rate at the study site (below the Ardag farm) was $5.6 \pm 1.1 \mathrm{~g}$ particulate organic carbon (POC) $\mathrm{m}^{-2} \mathrm{~d}^{-1}$ (Katz 2000) and the current direction in the region of the fish farm was generally along-shore (i.e. alternating easterly and westerly). The mean current velocity in the area was $20 \mathrm{~cm} \mathrm{~s}^{-1}$ during winter and $5 \mathrm{~cm} \mathrm{~s}^{-1}$ during summer (Brenner et al. 1989, Genin \& Paldor 1991). The surface water temperatures and salinities in the Gulf range from $20.6^{\circ} \mathrm{C}$ in late winter to $27^{\circ} \mathrm{C}$ in summer and from 40.3 to $40.8 \%$, respectively, and the water column is highly oxygenated (90 to $100 \%$ saturation) throughout the year (Reiss \& Hottinger 1984). The sediment at the northern end of the Gulf consists largely of alluvial silt and fine sand that supports mostly softbottom invertebrates and seagrasses (Fishelson 1971).

\section{MATERIALS AND METHODS}

Experimental design. In order to quantify the effect of gray mullets on the sediment below the farm, the mullets were placed in benthic enclosures, and changes in sediment indicators were monitored. To separate the mullets' effect on the sediment from the effects of the benthic enclosures and from natural changes in the bare sediments, we examined these variables in 3 types of $1 \mathrm{~m}^{2}$ benthic sampling stations: (1) 4 benthic enclosures stocked with mullets wherein the fish had access to the enclosed sediments (F) (see Fig. 1); (2) 3 empty enclosures (C); and (3) 3 unenclosed (bare sediment) stations (OP). Four enclosures, rather than just 3, were stocked with mullets in anticipation of the possibility that mullets in one of the cages might 
escape or die of disease, and thereby deprive us of the possibility of calculating a mean and variance for the resultant fish growth and sediment biogeochemistry data. The experiment was conducted on a rectangular area of seafloor measuring $8 \times 9 \mathrm{~m}$, directly below the fish farm.

The benthic enclosures were bottomless $1 \mathrm{~m}^{3}$ cubeshaped cages made of polyvinyl chloride (PVC)-coated net material $(20 \mathrm{~mm}$ mesh; Fischtechnik, Fredelsloh, Germany). The mesh sides of the enclosure were sewn onto a square iron base $(1 \times 1 \mathrm{~m})$ that was forced into the sediment (10 cm depth), where it served both as an anchor for the enclosure and to prevent the escape of mullets by digging under the bottom of the enclosure. The taut shape of the enclosures was maintained with the aid of buoys and cement anchors. A zipper $(40 \mathrm{~cm})$ was sewn into the center of one of the sides of each enclosure to enable stocking of the F enclosures with mullets and sampling of the sediments within all of the enclosures. Four groups of gray mullets (12 fish group $^{-1}$, average fish weight $144 \pm 34 \mathrm{~g}$ ) were transferred to the $\mathrm{F}$ enclosures under the Ardag farm on July 20, 1998. The stocking density of mullets used in this study $\left(1720 \pm 25 \mathrm{~g} \mathrm{~m}^{-2}\right)$ was chosen following a preliminary unpublished field trial with similar mullet stocking densities and the preliminary observations of Porter et al. (1996). Weekly dives were made throughout the study to observe the general health and behavior of the mullets and the structural integrity of the enclosures.

Sediment sampling. Sediments were sampled on July 12, 1998, 1 wk before the enclosures were placed on the seafloor and stocked with mullets, and 2 mo later, on September 23 to 24, 1998. At each sampling, sediment cores were taken from a different spot within the designated benthic sampling stations to avoid artifacts associated with taking sediment cores from the same spot on subsequent sampling dates. Sediment cores were removed at each station using clear PVC tubes (length $30 \mathrm{~cm}$, inner diameter $4.5 \mathrm{~cm}$ ). Samples were taken such that the tubes contained $18 \mathrm{~cm}$ of sediment, overlaid with $10 \mathrm{~cm}$ of seawater and sealed with rubber stoppers. Special care was taken to avoid disruption of the original stratification of the sediments. All core samples were rushed from the sea to the laboratory (room temperature $23^{\circ} \mathrm{C}$ ); stoppers were removed upon arrival, and the overlying water was not stirred during measurements. Chemical analyses were carried out within less than $1 \mathrm{~h}$ from the time the cores were removed from the seafloor. Prior to the geochemical analyses (see below), we counted the number of Nassarius sinusigerus snails present at the surface of each core. We counted only these snails and not other macrofauna in the sediment samples because they were large, the living individuals were readily enu-

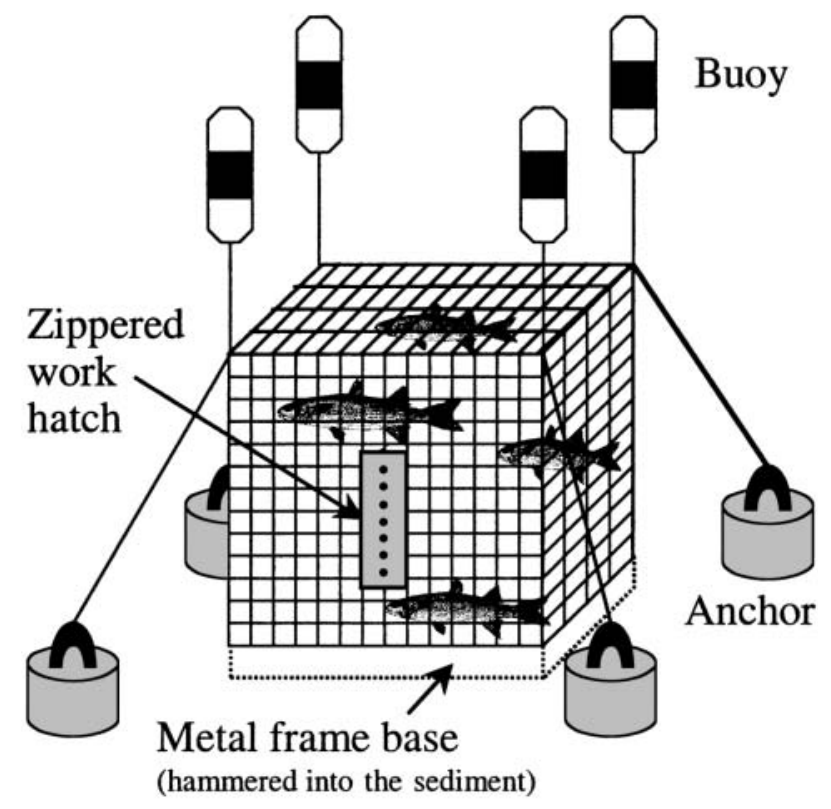

Fig. 1. Sketch of a $1 \mathrm{~m}^{3}$ (1 $\mathrm{m}$ width, $1 \mathrm{~m}$ height) benthic enclosure stocked with mullets

merated, and it was essential to carry out the geochemical analyses as soon as possible after reaching the laboratory in order to avoid artifacts related to oxygen depletion and sulfide accumulation.

Sediment analyses. The sediment cores were probed using DO and sulfide needle electrodes (Microscale Measurements). The sulfide needle electrodes were accompanied by a mini-pH electrode to yield total dissolved sulfides (TDS) concentration. Integrated sulfide values in the upper $3 \mathrm{~cm}\left(\mathrm{mmol} \mathrm{m}^{-2}\right)$ were obtained by multiplying the mean solute concentration in the upper $3 \mathrm{~cm}$ by (volume of porewater in upper $3 \times 100 \times$ $100 \mathrm{~cm}$ ). Following this the sediment was sliced to determine water content (WC) and loss-on-ignition (LOI) (Table 1). Additional samples were taken for sediment stratigraphy (see below). In order to convert the LOI values to POC, a set of samples with variable organic content was prepared from sediments taken from below the Ardag farm and triplicate subsamples were analyzed for both POC (after Raveh \& Avnimelech 1972) and LOI. A highly significant positive linear correlation $(p<0.01)$ was found between these variables, whereby

$$
\text { POC }(\%)=0.4577(\text { LOI })-0.0639\left(R^{2}=0.95, n=10\right)
$$

$\mathrm{POC}$ content (POCC) in the top $3 \mathrm{~cm}$ layer of sediment was normalized to $\mathrm{kg} \mathrm{m}^{-2}$, using the cross-sectional area of the cores $\left(15.9 \mathrm{~cm}^{2}\right)$.

Sediment stratigraphy. Sediment cores were taken $126 \mathrm{~d}$ after the enclosures were initially stocked with 
Table 1. Summary of methods used to determine vertical profiles of sediment geochemical variables in this study: water content, loss-on-ignition (LOI), particulate organic carbon (POC), dissolved oxygen (DO), total dissolved sulfides (TDS) and stratigraphy. The vertical resolution specified indicates the increments in which the profiles were performed, and the values in parentheses are the depth range examined

\begin{tabular}{|c|c|c|c|c|}
\hline Measured variable & Procedure & Vertical resolution & Profiling method & Source \\
\hline Water content & $\begin{array}{l}\text { Drying oven } \\
\left(105^{\circ} \mathrm{C}_{i}>24 \mathrm{~h}\right)\end{array}$ & $1 \mathrm{~cm}(0$ to $-4 \mathrm{~cm})$ & Slicing cores & Boyd (1995) \\
\hline LOI, POC & $\begin{array}{l}\text { Muffle furnace } \\
\left(450^{\circ} \mathrm{C}_{;} 8 \mathrm{~h}\right)\end{array}$ & $1 \mathrm{~cm}(0$ to $-4 \mathrm{~cm})$ & Slicing cores & Hakanson \& Jansson (1983) \\
\hline DO & $\begin{array}{l}\text { Polarographic } \\
\text { electrode }\end{array}$ & $0.5 \mathrm{~mm}(+14$ to $-4 \mathrm{~mm})$ & $\begin{array}{l}\text { Manual milli- } \\
\text { manipulator }\end{array}$ & Visscher et al. (1991) \\
\hline TDS & Sulfide electrode & $0.5 \mathrm{~cm}(+1$ to $-4 \mathrm{~cm})$ & $\begin{array}{l}\text { Manual milli- } \\
\text { manipulator }\end{array}$ & van Gemerden et al. (1989) \\
\hline $\begin{array}{l}\text { Sediment } \\
\text { stratigraphy }\end{array}$ & $\begin{array}{l}\text { Granulometry, } \\
\text { sediment color }\end{array}$ & $2 \mathrm{~cm}(0$ to $-12 \mathrm{~cm})$ & Slicing cores & Hakanson \& Jansson (1983) \\
\hline
\end{tabular}

mullets as follows: 3 cores were taken from each of 2 mullet and 2 empty (unstocked) enclosures, 2 cores were taken from each of 2 unenclosed stations, and 4 cores were taken from a station located $120 \mathrm{~m}$ west of the Ardag farm (120W), outside the zone of acute fish farm influence (Angel et al. 1998). In all but those cores taken from the $120 \mathrm{~W}$ station, there was a dark gray, almost black layer of fish farm sediment (FFS) superimposed over a light gray layer. The thickness of the dark gray upper layer was measured at 3 equally spaced intervals around the perimeter of each core, and then five $2 \mathrm{~cm}$ thick slices were cut from the sediment core: 2 from above the boundary between the dark and light gray layers and 3 from below. The 2 slices from the top dark gray layer were marked D1 and D2, and the 3 slices from the underlying light gray layer were marked L1, L2 and L3. Subsamples of the sediment slices were processed for WC, LOI and grain size distribution (granulometry). Average and median grain size, as well as skewness of the size distributions of the sand, were obtained from cumulative frequency curves (Hakanson \& Jansson 1983). Weight ratios of silt and gravel were measured as well.

Sediment oxygen demand (SOD). SOD may be calculated from DO concentration microgradients determined within the benthic diffusive boundary layer. However, because the equipment used in this study did not enable us to accurately resolve DO concentrations within the diffusive boundary layer, we used the following approach: SOD was calculated by measuring the depletion rate of DO in the water overlying the sediment inside uncapped PVC tubes, in the laboratory. Oxygen depletion rates of 3 sediment cores sampled from each station were plotted against time and yielded a negative linear correlation, which indicated a steady change in the oxygen depletion rate after the removal of the stoppers.
In order to calculate SOD, as described above, we relied on the following facts: (1) the difference between in situ water temperature and room temperature was small $(\leq 10 \%)$ and $(2)$ the ambient DO level in the overlying water was $95 \%( \pm 5 \%)$ saturation. We assumed that (1) DO concentration in the centimeter above the sediment surface represents the DO concentration throughout the core (see Fig. 4); (2) the sediment was fairly homogeneous at each sampling station; and (3) since the FFSs were highly organic, the contribution of the water column oxygen demand to the total oxygen demand in the cores was negligible.

From the constant change in the oxygen depletion rate within the sediment cores, we extrapolated back to the time just before we removed the stoppers. SOD was corrected to compensate for photosynthetic oxygen production by multiplying the results by 1.72 . This factor was obtained from the SOD rates in opaque versus transparent benthic flux chambers placed on bare sediments under the Ardag fish farm at the same depths (Angel 1996).

The differences in sediment geochemistry among the 3 treatments ( $F, C$ and $O P$ ) were examined by performing pairwise Student's $t$-tests, whereas differences in snail abundances in the 3 treatments were analyzed by the Mann Whitney $U$-test (pairwise comparison) and the Bonferroni correction method for multiple comparisons (Brown \& Rothery 1993). In addition, 1-way ANOVAs were conducted on the geochemical data obtained after $60 \mathrm{~d}$ of experiment to assess whether the main source of variance was between replicates or between treatments. The significances of the regression lines calculated for SOD rates were analyzed by the REG procedure of the SAS statistical package (SAS Institute). 


\section{RESULTS}

\section{General observations}

There were no mullet mortalities during the experiment; however, 1 mullet escaped from an enclosure 1 mo after the start of the experiment. The mullets did not seem adversely affected by the conditions in the enclosures, specifically the lack of oxygen or presence of hydrogen sulfides in the sediments, since the fish were observed actively digging in the organically enriched seabed. Mullets were also observed feeding on detritus that fell onto or into the enclosures.

In addition to the mullets in the enclosures, many (actual number was not determined) small (1 to $5 \mathrm{~g}$ ) fish (mostly the damselfish Neopomacentrus miryae) inhabited each of the mullet and unstocked enclosures. Because most of these fish were planktivores that did not feed from the sediment, we assumed that these did not bias the results. Local demersal fish species such as Parupeneus forsskali (goatfish) and Siganus luridus (rabbitfish) were too large to enter the enclosures; therefore, resuspension by fish within the enclosures was almost exclusively due to mullet activity. Local demersal fish resuspended the sediments and caused bioturbation of the bare seafloor below the farm.

Live Nassarius sinusigerus snails were not found in the cores from stations sampled at the beginning of the experiment. However, 2 mo later, the abundance of $N$. sinusigerus was significantly higher $(p<0.05)$ in samples taken from the mullet enclosures (mean \pm standard error [SE] $3970 \pm 1194$ snails $\mathrm{m}^{-2}$ ) than in those from the unenclosed sites $\left(457 \pm 256\right.$ snails $\left.\mathrm{m}^{-2}\right)$ and the empty control enclosures $\left(0 \pm 0\right.$ snails $\left.\mathrm{m}^{-2}\right)$. The differences between snail abundances in the unenclosed sites and the control enclosures were not statistically significant. Sample sizes were 16, 12 and 12 for F, C and $\mathrm{OP}$, respectively.

It is clear that the enclosures altered the pattern and velocity of water flow across the enclosed sediments, as well as the access of fauna to these sediments. However, we believe that the effect was quite similar between the stocked and unstocked enclosures since the replicated structures were identical, i.e. our controls were adequate.

\section{Sediment stratigraphy}

The granulometric attributes of dark gray FFS (slices D1 and D2) were significantly different from those of the underlying light gray layer (slices L1, L2 and L3) in all treatments (Table 2). Sediments from the L1, L2 and L3 slices from all stations were essentially the same with regard to percentage gravel, percentage silt, percentage water, LOI, median, mean and skewness of the sand fraction. Comparison of the sediment characteristics of the various slices showed that L1, L2 and L3 from all cores grouped together; these were significantly different $(p<0.001)$ from the pooled summary of slices D1 and D2. D2 sediments were always different from D1 sediments and mostly had values that were intermediate between those of D1 and of slices L1 to L3. The properties of the clean sediment from the station $120 \mathrm{~m}$ west of the farm were similar to those of the light gray slices (L1, L2 and L3) below the dark FFS. The layer of FFS was significantly thicker $(p<0.01)$ in the control enclosures $(8.4 \pm 2.1 \mathrm{~cm})$ and in unenclosed sites $(7.8 \pm 1.5 \mathrm{~cm})$ than in the mullet enclosures $(3.4 \pm$ $1.2 \mathrm{~cm}$ ) (Fig. 2).

\section{Sediment geochemistry}

With the exception of DO and TDS profiles (Figs. 3 $\& 4$, respectively), the geochemical data are presented between 0 and $3 \mathrm{~cm}$ below the sediment surface (Table 3), because we found that the impact of the mullets was greatest in the upper $3 \mathrm{~cm}$ of the sediment.

Prior to deployment of the enclosures, there were no significant differences in the measured variables (DO, hydrogen sulfide, sediment WC, LOI, SOD and POC) at the 3 sampling stations (Table 3, Figs. 3 \& 4). Moreover, at the unenclosed stations, there were no signifi-

Table 2. Summary of the geochemical (\% water, loss-on-ignition [LOI]) and granulometric (mean grain size, \% silt, \% gravel) properties of the dark grey (D1, D2) fish farm sediment slices and the underlying, light grey (L1, L2, L3) slices. All values are mean \pm SE $(n=16)$

\begin{tabular}{|lccccc|}
\hline Slice & \% water & LOI & Mean grain size, $\phi$ & $\%$ silt $<62 \mu \mathrm{m}$ & \% gravel $>2 \mathrm{~mm}$ \\
\hline D1 & $32.8 \pm 1.1$ & $3.70 \pm 0.31$ & $1.10 \pm 0.04$ & $1.0 \pm 0.2$ & $3.70 \pm 0.70$ \\
D2 & $28.3 \pm 0.9$ & $2.80 \pm 0.22$ & $1.38 \pm 0.08$ & $12.3 \pm 2.2$ & $2.50 \pm 0.54$ \\
L1 & $24.7 \pm 0.4$ & $1.84 \pm 0.09$ & $1.96 \pm 0.04$ & $20.1 \pm 1.2$ & $0.50 \pm 0.09$ \\
L2 & $23.7 \pm 0.3$ & $1.85 \pm 0.11$ & $1.97 \pm 0.13$ & $20.4 \pm 1.5$ & $0.57 \pm 0.17$ \\
L3 & $24.4 \pm 0.5$ & $1.83 \pm 0.14$ & $1.96 \pm 0.04$ & $23.5 \pm 1.4$ & $0.30 \pm 0.07$ \\
\hline
\end{tabular}




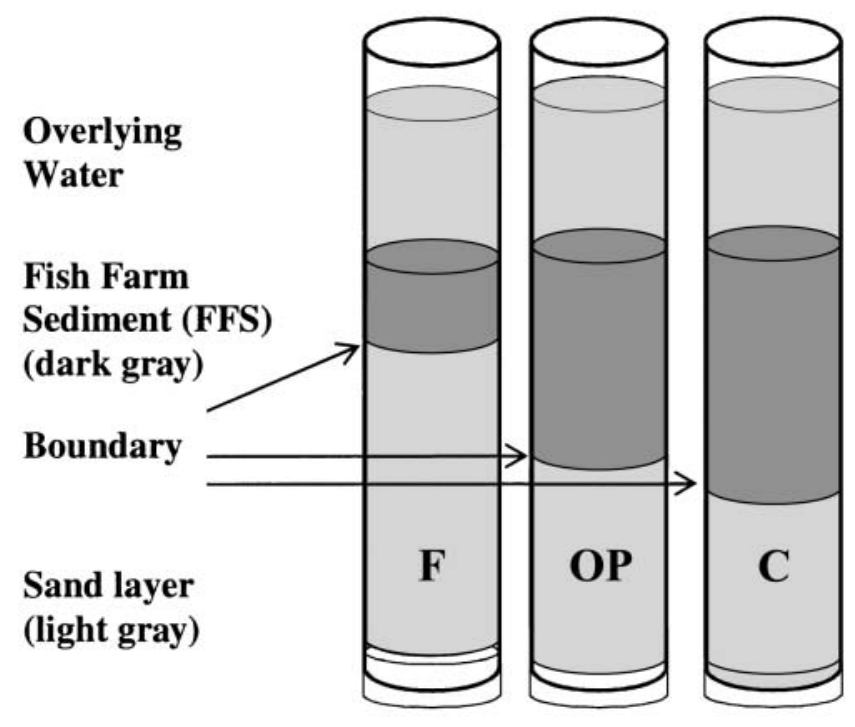

Fig. 2. Sketch of sediment stratigraphy in cores from unenclosed sediments (OP) and mullet (F) and unstocked (C) enclosures taken $126 \mathrm{~d}$ after the beginning of the experiment. The mean thickness of the dark gray fish farm sediment (FFS) layer $( \pm \mathrm{SE} ; \mathrm{n}=6$ for $\mathrm{F}$ and $\mathrm{C}, \mathrm{n}=4$ for $\mathrm{OP})$ was $3.4 \pm 1.2 \mathrm{~cm}$ in $\mathrm{F}, 7.8 \pm 1.5 \mathrm{~cm}$ in $\mathrm{OP}$ and $8.4 \pm 2.1 \mathrm{~cm}$ in $\mathrm{C}$

cant differences in these variables between the start of the study and 2 mo later. After $60 \mathrm{~d}$, the mean DO concentrations in the water above the sediment were significantly different between the 3 treatments (Fig. 3), such that $\mathrm{DO}_{\mathrm{F}}>\mathrm{DO}_{\mathrm{OP}}>\mathrm{DO}_{\mathrm{C}}$, and there were significant differences in TDS among the treatments such that $\operatorname{TDS}_{\mathrm{C}}>\mathrm{TDS}_{\mathrm{OP}}>\operatorname{TDS}_{\mathrm{F}}$ (Fig. 4, Table 3). The mean

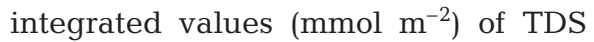
( 0 to $3 \mathrm{~cm}$ depth) in the mullet sediments after $60 \mathrm{~d}$ were 5- and 7 -fold lower than those in the unenclosed and empty enclosure sediments, respectively. The SOD (mean $\pm \mathrm{SE}_{;} \mathrm{n}$ ) was essentially the same among the treatments at the outset of the field experiment $\left(234 \pm 20 \mathrm{mmol} \mathrm{m}^{-2} \mathrm{~d}^{-1} ; 6\right)$. However, after $60 \mathrm{~d}$, SOD was $310 \pm 69$ (4), $705 \pm 129$ (3) and $447 \pm 64$ (3) mmol $\mathrm{m}^{-2} \mathrm{~d}^{-1}$ in the mullet enclosure, empty enclosure and unenclosed treatments, respectively. Statistical analyses of the SOD data revealed the following: (1) all regression lines were significant, (2) all intercepts (3 treatments) were significantly different $(\mathrm{p}<0.01$ confidence level) and (3) slopes of the 3 treatments were significantly different at the $\mathrm{p}<$ 0.05 level, except between $\mathrm{F}$ and $\mathrm{OP}$, which were different at the $\mathrm{p}<0.076$ level.
Whereas at the beginning of this study there were no substantial differences between sampling stations with regard to $\mathrm{WC}$ and POC (Table 3), after $60 \mathrm{~d}$, the order of $\mathrm{WC}$ and $\mathrm{POC}$ in the top $3 \mathrm{~cm}$ of the sediment was $\mathrm{WC}_{\mathrm{C}}>\mathrm{WC}_{\mathrm{OP}}>\mathrm{WC}_{\mathrm{F}}$ and $\mathrm{POC}_{\mathrm{C}}>\mathrm{POC}_{\mathrm{OP}} \geq \mathrm{POC}_{\mathrm{F}}$ respectively. As a result, the $\mathrm{POCC}$, i.e. the integrated POC values $\left(\mathrm{kg} \mathrm{m}^{-2}\right)$ in the top $3 \mathrm{~cm}$ of the sediment, did not vary significantly among the treatments at the 2 sampling times (Table 3). One-way ANOVAs were conducted on the results obtained after $60 \mathrm{~d}$ of experiment, and these indicated that after $60 \mathrm{~d}$ the differences between mullet enclosures (F), empty enclosures (C) and unenclosed sediments (OP) were the major sources of variance in all of the measured geochemical variables (Table 4), with the exception of the POCC in the top $3 \mathrm{~cm}$ of the sediment.

\section{DISCUSSION}

The biogeochemical data indicate that the sediments in the unstocked enclosures (C) had the highest OM levels and were the most affected. We believe that the low-current velocity within enclosures caused increased sedimentation rates and lower sediment scouring rates. The enclosures also prevented local demersal fish such as Parupeneus forsskali and Siganus luridus from entering and bioturbating or resuspending these sediments. Moreover, the low-current speed within the enclosures probably limited the flux of DO across the diffusive boundary layer and into the sediment, as described by Jorgensen \& Des Marais (1990) and Findlay

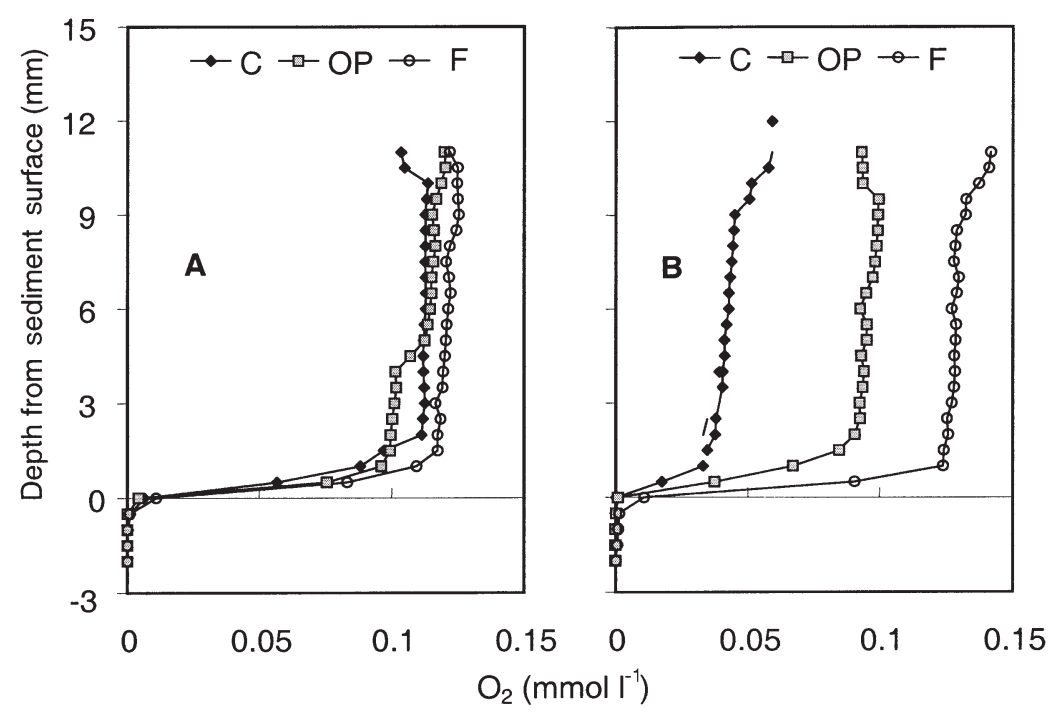

Fig. 3. Vertical profiles of dissolved oxygen concentration $\left(\mathrm{mmol} \mathrm{l}^{-1}\right)$ in cores taken from unenclosed sediments (OP) and mullet (F) and unstocked (C) enclosures at the (A) beginning (July 1998) and (B) end (September 1998) of the study 
Table 3. Summary of mean values of water content (WC), loss-on-ignition (LOI) and particulate organic carbon (POC) expressed as percentage sediment dry weight (\%DW), POC content $\left(\mathrm{kg} \mathrm{m}^{-2}\right)$ and total dissolved sulfides (TDS, $\left.\mathrm{mmol} \mathrm{m}^{-2}\right)$ in the top $3 \mathrm{~cm}$ of the sediment at the beginning $\left(T_{0}\right)$ and at the end $\left(T_{\mathrm{f}}\right)$ of the study. All values are mean \pm standard error. Pairwise $t$-tests were performed among the treatments at each of the sampling dates. ${ }^{*} \mathrm{p}<0.05 ;{ }^{* *} \mathrm{p}<0.01$; ns: not significant $(\mathrm{p}>0.05)$

\begin{tabular}{|c|c|c|c|c|c|c|c|c|}
\hline Variable & Units & $\begin{array}{l}\text { Sampling } \\
\text { date }\end{array}$ & $\mathrm{C}$ & $\begin{array}{c}t \text {-test } \\
\mathrm{H}_{0}: \mathrm{C}=\mathrm{OP}\end{array}$ & OP & $\begin{array}{c}t \text {-test } \\
\mathrm{H}_{0}: \mathrm{OP}=F\end{array}$ & $F$ & $\begin{array}{c}t \text {-test } \\
\mathrm{H}_{0}: F=\mathrm{C}\end{array}$ \\
\hline \multirow[t]{2}{*}{ WC } & $\% \mathrm{DW}$ & $T_{0}$ & $36.8 \pm 1.2$ & ns & $35.8 \pm 0.3$ & ns & $36.2 \pm 0.6$ & ns \\
\hline & & $T_{\mathrm{f}}$ & $49.7 \pm 1.1$ & $* *$ & $39.3 \pm 0.8$ & $* *$ & $33.7 \pm 0.5$ & $* *$ \\
\hline \multirow[t]{2}{*}{ LOI } & $\% \mathrm{DW}$ & $T_{0}$ & $4.40 \pm 0.26$ & ns & $4.50 \pm 0.19$ & ns & $4.10 \pm 0.17$ & ns \\
\hline & & $T_{\mathrm{f}}$ & $6.20 \pm 0.22$ & $* *$ & $4.60 \pm 0.19$ & ns & $4.10 \pm 0.12$ & $* *$ \\
\hline \multirow[t]{2}{*}{ POC } & $\% \mathrm{DW}$ & $T_{0}$ & $1.97 \pm 0.11$ & ns & $2.01 \pm 0.09$ & ns & $1.81 \pm 0.08$ & ns \\
\hline & & $T_{\mathrm{f}}$ & $2.77 \pm 0.10$ & $* *$ & $2.03 \pm 0.09$ & ns & $1.82 \pm 0.05$ & $* *$ \\
\hline \multirow[t]{2}{*}{ POC content } & $\mathrm{kg} \mathrm{m}^{-2}$ & $T_{0}$ & $1.60 \pm 0.08$ & ns & $1.60 \pm 0.16$ & ns & $1.42 \pm 0.04$ & ns \\
\hline & & $T_{\mathrm{f}}$ & $1.40 \pm 0.06$ & ns & $1.30 \pm 0.04$ & $\mathrm{~ns}$ & $1.35 \pm 0.04$ & $\mathrm{~ns}$ \\
\hline \multirow[t]{2}{*}{ TDS content } & $\mathrm{mmol} \mathrm{m}^{-2}$ & $T_{0}$ & $27.3 \pm 4.2$ & ns & $14.4 \pm 2.6$ & ns & $16.1 \pm 1.6$ & ns \\
\hline & & $T_{\mathrm{f}}$ & $39.6 \pm 5.0$ & * & $28.2 \pm 4.2$ & ${ }^{* *}$ & $5.5 \pm 1.2$ & *** \\
\hline
\end{tabular}

\& Watling (1997). Under such oxygenlimited and organically enriched conditions, there was an increase in TDS levels within the unstocked enclosure sediments (Fig. 4, Table 3), probably due to proliferation of anaerobic microflora (mostly sulfate-reducing bacteria) as was shown by Holmer \& Kristensen (1992).

Within the mullet enclosures $(\mathrm{F})$, mullets were observed digging vigorously and resuspending the sediments while they swam. Thus, despite the heavy loading of OM in all of the enclosures, the mullets probably increased the oxygen supply to the sediment, thereby restricting the activity of benthic anaerobes (Madigan et al. 2000) and possibly increasing the OM decomposition rate. As shown by Hulthe et al. (1998), OM buried in anoxic sediments may be more rapidly decomposed once it is resuspended and exposed to oxygen.

The sediment oxygen concentration in all treatments was undetectable beyond $0.5 \mathrm{~mm}$ below the sediment surface, due to the high organic content of the sediment and the intense microbial activity therein (Chanton et al. 1987, Visscher et al. 1991). Whereas the sediment porewater near the surface $(0$ to $0.5 \mathrm{~mm})$ was hypoxic $\left(<0.045 \mathrm{mmol} \mathrm{l}^{-1}\right.$, as defined by Diaz \& Rosenberg 1995) at the beginning of the study, there was slight, yet statistically significant oxygen penetration (mean \pm SE $0.46 \pm$ $0.27 \mathrm{~mm}$ ) into the mullet sediments

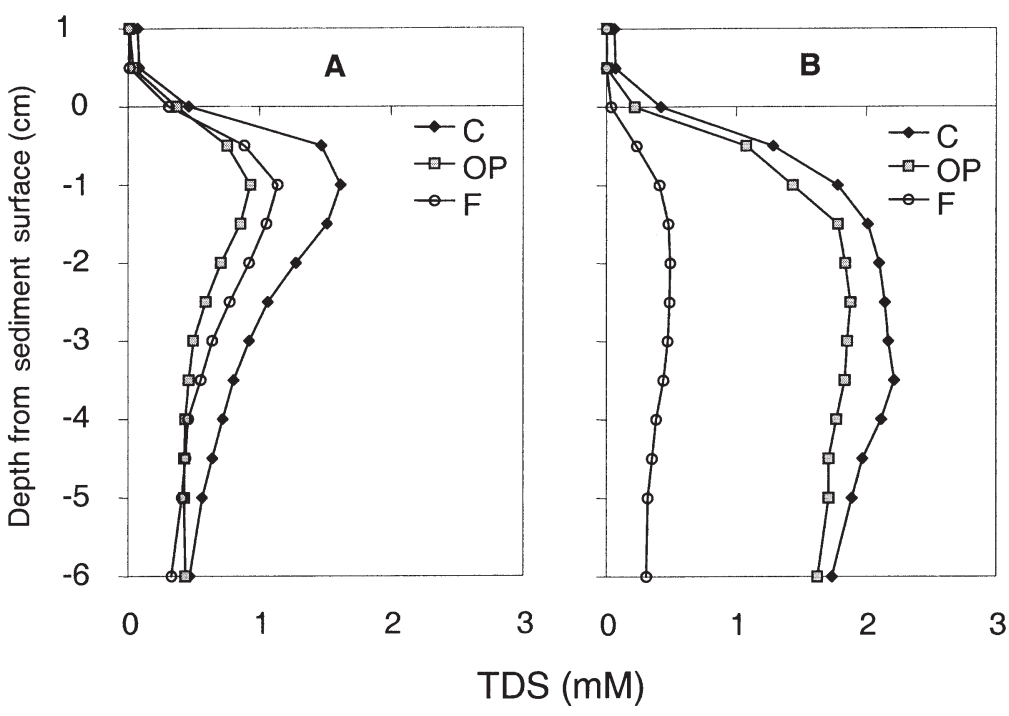

Fig. 4. Vertical profiles of total dissolved sulfides (TDS) concentration (mM) in cores taken from unenclosed sediments (OP) and mullet (F) and unstocked (C) enclosures at the (A) beginning (July 1998) and (B) end (September 1998) of the study

Table 4. Statistical results of individual comparisons between mullet enclosures, empty enclosures and unenclosed sites at the end of this study $\left(T_{\mathrm{f}}\right)$ using 1-way ANOVA, in terms of sediment loss-on-ignition (LOI), water content (WC), organic carbon (OC), total dissolved sulfides (TDS) and dissolved oxygen (DO). $\mathrm{DF}_{\mathrm{M}}$ and $\mathrm{DF}_{\mathrm{E}}$ are model and error degrees of freedom, respectively; $\mathrm{MS}_{\mathrm{M}}$ and $\mathrm{MS}_{\mathrm{E}}$ are model and error mean squares, respectively

\begin{tabular}{|lcrrrrr|}
\hline Variable & $\mathrm{DF}_{\mathrm{M}}$ & $\mathrm{MS}_{\mathrm{M}}$ & $\mathrm{DF}_{\mathrm{E}}$ & $\mathrm{MS}_{\mathrm{E}}$ & $F$ ratio Probability $>F$ \\
\hline Sediment LOI & 2 & 3.64 & 7 & 0.13 & 28.19 & $<0.001$ \\
Sediment WC & 2 & 218.43 & 7 & 3.90 & 55.92 & $<0.001$ \\
Sediment OC & 2 & 0.004 & 7 & 0.011 & 0.33 & 0.73 \\
Porewater TDS & 2 & 1091.91 & 7 & 29.11 & 37.51 & $<0.001$ \\
DO in overlying water & 2 & 6.48 & 7 & 0.50 & 12.86 & $<0.005$ \\
DO at sediment surface & 2 & 0.11 & 7 & 0.02 & 5.50 & $<0.05$ \\
& & & & & & \\
\hline
\end{tabular}


after $60 \mathrm{~d}$, as compared to undetectable DO in the unenclosed (OP) and unstocked enclosure sediments (Fig. 3). The penetration of oxygen into the sediment due to the activity of benthic macrofauna is well documented (Aller 1977 and others), yet it is considered negligible in highly organic, hypoxic sediments such as those found under many fish farms, since hypoxic and sulfidic environments are hostile to most benthic fauna (Parsons et al. 1977). In this study, the demersal mullets did not appear to be affected by the sulfides or the hypoxic conditions in the sediments and acted as efficient biotubators of the noxious sediments.

Despite the fact that we used a relatively crude method to measure SOD, the SOD rates we recorded at the unenclosed sediment stations (OP: 234 and $447 \mathrm{mmol} \mathrm{m}^{-2} \mathrm{~d}^{-1}$, at the start and end of the study, respectively) were similar to the rates measured by Angel (1996) at the same site using benthic flux cham-

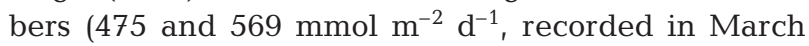
and August 1996, respectively). The temporal increase in SOD rates in the unenclosed sediments during this study (234 to $447 \mathrm{mmol} \mathrm{m} \mathrm{m}^{-2} \mathrm{~d}^{-1}$ ) might be related to (1) accumulation of fish feed in the sediments - feeding rates generally peak during the summer (July to October, the period during which this study was done) and may lead to accumulation of uneaten fish feed in the sediment-and (2) slow currents (and therefore reduced sediment scouring) at the study site, in the vicinity of the enclosures, causing POM to accumulate. The SOD rates measured within the unstocked enclosures were only slightly higher than the maximal rates measured in bare sediments below the Ardag cages (Angel et al. 1995) and were generally within the same range as those reported by Holmer \& Kristensen (1992) and $\mathrm{Wu}$ et al. (1994). In comparison, the low SOD rates in the mullet enclosures were probably the result of low-sediment organic content and highly resuspended sediments. It is noteworthy that there was a slight temporal rise in SOD in the F enclosures (from 234 to $310 \mathrm{mmol} \mathrm{m}^{-2} \mathrm{~d}^{-1}$ ), over the course of the study. The enhanced SOD was probably related to the dramatically increased abundances of Nassarius sinusigerus population in the mullet enclosure sediments (from 0 to 3970 snails $\mathrm{m}^{-2}$ ), since it has been shown that macrofauna respiration can have a significant impact on sediment respiration (Kristensen et al. 1992).

The decrease in DO in the cores brought from the field to the laboratory was due to SOD, which is influenced mainly by the presence of labile OM in the sediment and microbial metabolic activity therein (Archer \& Devol 1992, Banta et al. 1995). Evidently there was a temporal increase in sediment labile OM levels at the unenclosed (control) stations, since the DO concentrations in samples taken after $60 \mathrm{~d}$ were lower than those taken at the start of the study (Fig. 3).
There were substantial differences in both organic carbon concentration $\left(\mathrm{OC}_{\mathrm{C}}>\mathrm{OC}_{\mathrm{OP}} \geq \mathrm{OC}_{\mathrm{F}}\right)$ and $\mathrm{WC}$ $\left(\mathrm{WC}_{\mathrm{F}}<\mathrm{WC}_{\mathrm{OP}}<\mathrm{WC}_{\mathrm{C}}\right)$ in the 3 treatments. However, because both $\mathrm{OC}$ and WC were used to calculate POCC in the upper $3 \mathrm{~cm}$ layer and thxey were inversely related, the differences in POCC in the 3 treatments were essentially insignificant $\left(\mathrm{POC}_{\mathrm{C}} \approx\right.$ $\mathrm{POC}_{\mathrm{OP}} \approx \mathrm{POC}_{\mathrm{F}}$ ). Nonetheless, it is clear from both visual observations and sediment stratigraphy measurements that there was considerable removal of POC from the sediments in the mullet enclosures as compared to the unenclosed sites and the unstocked enclosures. The removal of organic sediment from within the mullet enclosures was directly estimated by measuring the thickness of the dark gray FFS layer (Fig. 2). This layer was $5 \mathrm{~cm}$ thicker in the unstocked enclosures than in the mullet enclosures, indicating that the mullets had removed approximately $50 \mathrm{l}$ of sediment $\mathrm{m}^{-2}(5 \times 100 \times 100 \mathrm{~cm})$ within a period of $126 \mathrm{~d}$, the time lapsed between deployment of the enclosures, and the sediment stratigraphy measurements. The mean POCC in the upper $3 \mathrm{~cm}$ layer of the sediment at the start of the study was $1.54 \mathrm{~kg}^{\mathrm{POC} \mathrm{m}} \mathrm{m}^{-2}$ (Table 3 ). In order to estimate the quantity of POC in the missing $5 \mathrm{~cm}$ thick layer in the F cages, we extrapolated (5/3) and multiplied this by the mean POCC: $5 / 3 \times 1.54 \mathrm{~kg}$ $\mathrm{POC}=2.56 \mathrm{~kg}$ POC. The daily removal rate was calculated by dividing the total amount of POC removed by $126 \mathrm{~d}=20.3 \mathrm{~g} \mathrm{POC} \mathrm{m}^{-2} \mathrm{~d}^{-1}$. Whereas we did not monitor the POC removal rate, this process was probably rapid at first and eventually decelerated as the organically rich sediment top layer was grazed and resuspended by the mullets.

In a study on detritus utilization by mullets, Odum (1970) estimated that a $20 \mathrm{~cm}$ fish can ingest up to $1500 \mathrm{~g}$ dry sediment $\mathrm{d}^{-1}$ while foraging for food. In processing such large amounts of detritus, the mullets cause a great deal of sediment resuspension (Oren 1981). I. Lupatsch \& T. Katz (unpubl.) examined the nutrition of gray mullets and focused on their use of fish farm detritus. Their study included fish growth data from land-based tanks and from the experimental mullet enclosures (F) described in this study, and they calculated that the ' $\mathrm{F}^{\prime}$ mullets utilized $4.4 \mathrm{~g} \mathrm{POC} \mathrm{\textrm {m } ^ { - 2 }} \mathrm{d}^{-1}$ and gained $0.47 \mathrm{~g}$ (biomass) $\mathrm{d}^{-1}$ fish $^{-1}$. Although some of the POC removed from the sediment was consumed by the mullets, we propose that the resuspension of this material by the fish accelerated its decomposition rate due to increased oxygen availability and larger surface area exposure of the resuspended particles (Hulthe et al. 1998). Indeed, Chrost \& Riemann (1994) have shown that $\mathrm{OM}$ in resuspended sediment undergoes much faster bacterial decomposition then in undisturbed sediment. 
A local gastropod population provided additional evidence of the improvement in conditions within the sediments of the mullet enclosures. The dominant macrofauna on the sediments below and near the fish farm was the mud snail Nassarius sinusigerus, which was attracted to the organically enriched benthos (Angel et al. 1998). This gastropod has limited tolerance to high concentrations of hydrogen sulfide and is generally more abundant at the outskirts of the farm than in the sediments directly below the fish cages. Therefore, the increased abundance of these gastropods within the mullet enclosures was most likely due to increased DO at and just below the sediment surface (Fig. 3) and the substantial reduction in subsurface sulfides (Fig. 4). Whereas mullets played a major role in mixing, oxygenating and resuspending the sediments, they were probably not the sole bioturbators. It has been shown that benthic invertebrates can contribute substantially to the bioturbation of the sediment (Aller 1977, Tsutsumi et al. 1991, Heilskov \& Holmer 2001); however, the snail bioturbation could only have occurred after the mullets had first conditioned the initially anaerobic, sulfidic sediments. It is noteworthy that in the case of many demersal fish species, sediment resuspension is the result of foraging for prey and may lead to a drop in abundance of benthic macrofauna (e.g. Riise \& Roos 1997, Svensson et al. 1999). In this study we have shown that mullets play an important role in sediment resuspension, yet the outcome of their foraging activity was the proliferation of the nassarid snails.

Whereas we have demonstrated that gray mullets within mesh enclosures may serve as efficient bioturbators of reduced, organically enriched sediments, our study covered very small plots of sediment $\left(1 \mathrm{~m}^{2}\right)$ and relatively brief (60 d) deployments. Upscaling of mullet enclosures to treat larger areas of affected sediments below fish farms involves several biological and logistical considerations beyond the scope of this paper. It is not clear whether the economical value of the mullets would offset the expenses involved in their deployment, maintenance and harvesting; however, it is possible that the environmental benefit gained by the enhanced sustainability of the fish farm with the mullets would justify their use.

\section{CONCLUSIONS}

The objective of this study was to determine whether gray mullets in benthic enclosures could reduce the organic load and some of the associated impacts in the sediments below a commercial farm. We have shown that the quantity of OM in the sediment was substantially reduced when $5 \mathrm{~cm}$ of FFS was removed by the mullets. We have also shown that the sediment in the mullet enclosures was more aerated and less sulfidic than in both unenclosed sediments and unstocked enclosures nearby. Moreover, there was a large increase in the abundance of opportunistic gastropods within the mullet enclosures as compared to the other treatments. It is remarkable that most of the changes described above occurred within 2 mo, and this suggests that short-term mullet deployments my enable substantial improvement in the quality of organically enriched sediments. Additional applied research is necessary to develop a practical, effective and economical benthic mullet culture system for treating organically enriched sediments under commercial marine fish farms.

Acknowledgements. The authors thank I. Lupatsch for her help with sediment analysis and for her invaluable input regarding mullet nutrition. Special thanks to N. Eden, A. Bannet and E. Hadas for their help with field and laboratory work, to G. Yahel for help with the statistical analyses and to ARDAG for assistance in purchasing the mullets and materials for construction of the enclosures, and for their help throughout the study. Thanks also to M. Holmer, J. Ackerman and 3 anonymous reviewers for providing constructive comments that helped improve the manuscript.

\section{LITERATURE CITED}

Ahlgren MO (1998) Consumption and assimilation of salmon net pen fouling debris by the red sea cucumber Parastichopus californicus: implications for polyculture. J World Aquac Soc 29:133-139

Aller RC (1977) The influence of macrobenthos on chemical diagenesis of marine sediments. PhD thesis, Yale University

Angel DL (1996) Report on environmental research. Annual report. National Center for Mariculture, Israel Oceanographic and Limnological Research, Eilat

Angel DL, Krost P, Gordin H (1995) Benthic implications of net cage aquaculture in the oligotrophic Gulf of Aqaba. Eur Aquac Soc Spec Publ 25:129-173

Angel DL, Post A, Brenner S, Eden N, Katz T, Cicelsky A, Lupatsch I (1998) Assessment of the environmental impact of the Ardag net cage fish farm on the northern Gulf of Aqaba. A study prepared for the Ardag Fish Company, Eilat (in Hebrew)

Archer D, Devol A (1992) Benthic oxygen flux on the Washington shelf and slope: comparison of in-situ microelectrode and chamber flux measurements. Limnol Oceanogr 37:614-629

Banta GT, Giblin AE, Hobbie JE, Tucker J (1995) Benthic respiration and nitrogen release in Buzzards Bay, Massachusetts. J Mar Res 53:107-135

Bergheim A, Aabel JP, Seymour EA (1991) Past and present approaches to aquaculture waste management in Norwegian net pen culture operations. In: Cowey $\mathrm{CB}, \mathrm{Cho} \mathrm{CY}$ (eds) Nutritional strategies and aquaculture waste. Proceedings of the First International Symposium on Nutritional Strategies in Management of Aquaculture Waste. University of Guelph, p 117-136

Beveridge MCM (1996) Cage aquaculture, 2nd edn. Fishing News Books, Oxford

Black KB (1998) The environmental interactions associated 
with fish culture. In: Black KD, Pickering AD (eds), Biology of farmed fish. CRC Press, Boca Raton, p 284-326

Boyd CE (1995) Bottom soils, sediment and pond aquaculture. Chapman \& Hall, New York

Braaten B, Ervik A, Boje E (1983) Pollution problems in Norwegian fish farms. Aquac Ireland 14:6-10

Brenner S, Rosentroub Z, Bishop Y (1989) Current measurements in the Gulf of Elat 1988/89. Report H8/89, Israel Oceanographic and Limnological Research, Haifa

Brown D, Rothery P (1993) Models in biology: mathematics, statistics and computing. John Wiley \& Sons, New York

Brown JR, Gowen RJ, Mclusky DS (1987) The effect of salmon farming on the benthos of a Scottish sea loch. J Exp Mar Biol Ecol 109:35-51

Chanton JP, Martens CS, Goldhaber MB (1987) Biogeochemical cycling in an organic-rich coastal marine basin. 7. Sulfur mass balance, oxygen uptake and sulfide retention. Geochim Cosmochim Acta 51:1187-1199

Chareonpanich C, Montani S, Tsutsumi H, Nakamura H (1994) An attempt to use a deposit feeding polychaete, Capitella sp. $\mathrm{I}$, as a purifier of the bottom sediments in coastal fishery areas. Asian Fisheries Society, Manila, p 31-34

Chrost RJ, Riemann B (1994) Storm-stimulated enzymatic decomposition of organic-matter in benthic pelagic coastal mesocosms. Mar Ecol Prog Ser 108:185-192

Diaz RJ, Rosenberg R (1995) Marine benthic hypoxia: a review of its ecological effects and the behavioral responses of benthic macrofauna. In: Ansell AD, Gibson RN, Barnes $\mathrm{M}$ (eds) Oceanography and marine biology. UCL Press, New York, p 245-303

Findlay RH, Watling L (1997) Prediction of benthic impact for salmon net-pens based on the balance of benthic oxygen supply and demand. Mar Ecol Prog Ser 155:147-157

Fishelson L (1971) Ecology and distribution of the benthic fauna in the shallow waters of the Red Sea. Mar Biol 10:113-133

Genin A, Paldor N (1991) Currents in the northern Gulf of Eilat. Ad Hoc Report to the Israeli Ministry of Transportation, Jerusalem (in Hebrew)

Gowen RJ, Smyth D, Silvert W (1994) Modeling the spatial distribution and loading of organic fish farm waste to the seabed. In: Hargrave BT (ed) Modelling benthic impacts of organic enrichment from marine aquaculture. Can Tech Rep Fish Aquat Sci 1949:19-30

Hakanson L, Jansson M (1983) Principles of lake sedimentology. Springer-Verlag, New York

Hall POJ, Anderson LG, Holby O, Kollberg S, Samuelsson MO (1990) Chemical fluxes and mass balances in a marine fish cage farm. I. Carbon. Mar Ecol Prog Ser 61:61-73

Heilskov AC, Holmer M (2001) Impacts of benthic fauna on organic matter mineralization in fish farm sediments: importance of size and abundance. ICES J Mar Sci 58: 427-434

Holmer M, Kristensen E (1992) Impact of marine fish cage farming on metabolism and sulfate reduction of underlying sediments. Mar Ecol Prog Ser 80:191-201

Hulthe G, Hulth S, Hall POJ (1998) Effect of oxygen on degradation rate of refractory and labile organic matter in continental margin sediments. Geochim Cosmochim Acta 62: $1319-1328$

Jorgensen BB, Des Marais DJ (1990) The diffusive layer of sediments: oxygen microgradients over a microbial mat. Limnol Oceanogr 35:1343-1355

Katz T (2000) Reduction of organic load in sediments under a marine fish farm by striped grey mullets. MSc thesis, Hebrew University, Jerusalem

Kristensen E, Andersen F, Blackburn TH (1992) Effect of macrofauna and temperature on degradation of macro- algal detritus: the fate of organic carbon. Limnol Oceanogr 37:1404-1419

Laffaille P, Bross S, Feunteun E, Baisez A, Lefeuvre JC (1998) Role of fish communities in particulate organic matter fluxes between salt marshes and coastal marine waters in Mont Saint Michel Bay. Hydrobiologia 373:121-133

Madigan MT, Martinko JM, Parker J (2000) Brock biology of microorganisms. Prentice Hall, London

Naylor RL, Goldburg RS, Primavera JH, Kautsky N and 6 others (2000) Effect of aquaculture on world fish supplies. Nature 405:1017-1024

O'Connor B, Costelloe J, Dineen P, Faull J (1993) The effect of harrowing and farrowing on sediment quality under a salmon farm on the west coast of Ireland. ICES Publ CM 1993/F 19:1-16

Odum WE (1970) Utilization of the direct grazing and plant detritus food chains by the striped mullet Mugil cephalus In: Steele J (ed) Marine food webs, a symposium. University of California Press, Berkeley, p 222-240

Oren OH (1981) Aquaculture of grey mullets. Cambridge University Press, London

Parsons TR, Takahashi M, Hargrave B (1977) Biological oceanographic processes. Pergamon Press, New York

Porter CB, Krost P, Gordin H, Angel DL (1996) Preliminary assessment of grey mullet (Mugil cephalus) as a forager of organically enriched sediments below marine fish farms. Isr J Aquac Bamidgeh 48:47-55

Raveh A, Avnimelech Y (1972) Potentiometric determination of soil organic matter. Proc Soil Sci Soc Am 36:967-968

Reiss Z, Hottinger L (1984) The Gulf of Aqaba: ecological micropaleontology. Springer-Verlag, New York

Riise JC, Roos N (1997) Benthic metabolism and the effects of bioturbation in a fertilised polyculture fish pond in northeast Thailand. Aquaculture 150:45-62

Shapiro J (1998) Food of the thin lipped grey mullet (Liza ramada) in Lake Kinneret, Israel. Isr J Aquac Bamidgeh 50:3-11

Silvert W, Sowles JW (1996) Modelling environmental impacts of marine finfish aquaculture. J Appl Ichthyol 12: $75-81$

Svensson JM, Bergman E, Andersson G (1999) Impact of cyprinid reduction on the benthic macroinvertebrate community and implications for increased nitrogen retention. Hydrobiologia 404:99-112

Tsutsumi H, Kikuchi T, Tanaka M, Higashi T, Imasaka $\mathrm{K}_{\text {, }}$ Miyazaki M (1991) Benthic faunal succession in a cove organically polluted by fish farming. Mar Pollut Bull 23: 233-238

Van Gemerden H, Tughan CS, de Wit R, Herbert RA (1989) Laminated microbial ecosystems on sheltered beaches in Scapa Flow, Orkney Islands. FEMS Microbiol Ecol 62: 87-102

Visscher PT, Beukema J, van Gemerden H (1991) In situ characterization of sediments: measurements of oxygen and sulfide profiles with a novel combined needle electrode. Limnol Oceanogr 36:1476-1480

Weston DP (1990) Quantitative examination of macrobenthic community changes along an organic enrichment gradient. Mar Ecol Prog Ser 61:233-244

Wu RSS, Lam KS, MacKay DW, Lau TC, Yam V (1994) Impact of marine fish farming on water quality and bottom sediment: a case study in the subtropical environment. Mar Environ Res 38:115-145

Yokoyama H, Abo K, Toyokawa M, Toda S, Yamamoto S (1997) Impact of mariculture on the spatial and temporal patterns of the macrobenthos in Gokasho Bay. Bull Natl Res Inst Aquac (Jpn) 3(Suppl):7-16 